\title{
DISCURSO DEL RECTOR DE LA UNIVERSIDAD NACIONAL DE SAN MARCOS
}

\author{
Dr D. Pedro Delanto
}

La Universidad Nacional Mayor de San Marcos, se asocia con profundo respeto en esta ocasión felizmente promovida por el distinguido Presidente de la Sociedad de Neuro Psiquiatría y Medicina Legal al homenaje universal que se dedica este año a uno de los más altos valcres de nuestra raza y signo encumbrado de la grandeza del Espíritu: Sontiago Ramón y Cajal. La Universidad, que confunde sus raíces históricas con las fuentes de la cuitura española, no podía permanecer indiferente ante una conmemoración de semejante trascendencia y por eso solidariza su actitud con totas las institucicnes sabias que recuerdan el fausto nacimiento del preclaro varón y aviva los sentimientos de su admiración para ofrendarlos a su esclarecida memoria.

Ramón y Cajal, en efecto, compendia en su vida y en su obra luminosa, cuanto puede ennoblecer $\alpha$ su Patria y a los pueblos que provienen de la misma estirpe. Es la suya una vida superior, normada par sacrificio ante un alto ideal. Ese idral es el de la ciencia entendida en la más generosa acepción del saber y el bien de la humanidad, sin limitaciones exclusivistas dictadas por la estrechez de la especialización. La ciencia es para él una depurada forma del conocimiento en estrecha comunicación con la filosoría, el arte, la literatura y las disciplinas sociales y políticas. Pudo llegar a esa concepción de la ciencia, solamente después de una rica tormación humanística que comenzó con sus abundantes lecturas filosóficas y literorias y aún con sus juveniles ensayos en la pintura y la novela. La amplitud del panorama no le destruyó, sin embargc, la más minuciosa contemplación de los detalles y antes le facilitó la concentración de su capacidad ideadora en un mundo hasta entonces misterioso y casi invisible, el de los 
tejidos nexviosos y sus inextricables vinculaciones con todo el organismo. Esa penetración luminosa en lo infinitamente delicado y diminuto la hizo sin olvidar los principios generales de la vida y la sociedad, la humonidad y la Patria, el destino del hombre y todos los valores que normon el desarrollo de la civilización. La ciencia contemporánea disgregada en una serie de truncas visiones, necesita cada vez más de estos elevados modelos para orientarse en el sentido de una armónica arquitectura, en todo benéfica para el género humano. El ideal científico concebido, reclama el servicio de una existencia singulur y Ramón y Cajal se la otorga sin vacilaciones y amoldando todos los elementos de su vida al cumplimiento de los principios rectores de su actividad como investigador y maestro. Resalta entre aquellos elementos, la poderosa voluntad que lo distigue desde sus años mozos, mediante la cual se impone a todas las contradicciones de un medio adverso, salvando las dificultades que la incomprensión, el interés o la envidia le van acumulando $y$, sobre todo, vence toda dispersión interior, toda tendencia hacia el placer infecundo, para condensar las energías creadoras en tomo al empeño supremo de su ser. Rápidarmente cumple de este modo las etapas de un itinerorio glorioso hasta alcomzar, antes de los cuarenta años, el pináculo de sus fundamentales descubrimientos. La celebridad, entonces, lo rodea. Ya no es la honra de España únicamente sino la honra de Europa y de la ciencia en general. El hombre hubiera podido descansar en más livianas tareas; pero el sabio continúa su labor sin tregua. En el recogimiento del laboratorio, de espaldas a todas las seducciones del mundo, alentado única. mente por el afecto de una familia ejemplar, prosigue en la explora. ción paciente y milagrosa de aquellas finísimes estructuras que constituyen la parte más noble de nuestro cuerpo. Predica la moral de morir en la brecha; perno no en la pelea sangrienta, sino en la lucha por la verdad y el amor entre los hombres y aconseja no desesperar con la vejez, la edad aparentemente sin mañana, sino crear para ella una esperanza tenaz, y "morir el labrador plantando un árbol, el escritor. llenondo una cucrtilla". Así murió él en 1934, en esfuerzo permanente $y$ en pugna no sólo por el triunto en el trabajo sino por el triunfo: en contra de la enlermedad que lo agobió en sus años postreros, con aquel carácter denodado que había sido la clave de sus pasados éxitos.

La Universidad, que oportunamente asimiló el valioso legado del Maestro, guarda perenne devoción a su genio y se complace en expresarla, por mi voz, en esta espléndida hora jubilar. 